\title{
Methane and Carbon Dioxide Flux from Rice Field: Contribution of Environmental Controls \\ M. B. Khan ${ }^{1}$, S. Boult ${ }^{1}$, P. Duy ${ }^{1}$, E. Sharmin ${ }^{2}$ and M. A. Baten ${ }^{2}$ \\ ${ }^{1}$ School of Earth, Atmospheric and Environmental Science, University of Manchester, UK \\ ${ }^{2}$ Department of Environmental Science, Bangladesh Agricultural University, Mymensingh
}

\begin{abstract}
An investigation was carried out to quantify the present fluxes of $\mathrm{CH}_{4}$ and $\mathrm{CO}_{2}$ from rice soils and also to investigate the controls on gas production. Soil samples were collected from rice field at Mymensingh, Bangladesh to characterize the samples and for ex-situ measurement. Water content was determined by drying to constant weight at $50{ }^{0} \mathrm{C}$ from rice soils. To determine the organic compound present in rice soil, normal pyrolysis was done. Gasclam ${ }^{\circledR}$ was used to measure the gas concentration from both ex-situ and in-situ measurement. Ex-situ measurement was conducted to measure the gas fluxes from the soil and which was validated by measuring concentration ratios in-situ. Moreover, in-situ measurement was carried out to investigate the influences of controls of environment on gas production and migration. In ex-situ measurement the production rate of $\mathrm{CH}_{4}$ at shallow and deep rice soil was $0.07 \mathrm{~mole} / \mathrm{tonne}$ dry weight/day and $0.09 \mathrm{~mole} / \mathrm{tonne}$ dry weight/day, respectively. On the otherhand, the production rate of $\mathrm{CO}_{2}$ in shallow and deep borehole was $0.23 \mathrm{~mole} /$ tonne dry weight/day and 0.29 mole/tonne dry weight/day, respectively. In in-situ measurement the average production rate of $\mathrm{CH}_{4}$ in shallow soil was $0.34 \%$ while at deep soil it was very low. The $\mathrm{CO}_{2}$ concentration at shallow and deep soil was $6.37 \%$ and $24.70 \%$, respectively. The ex-situ measurements of greenhouse gas fluxes are not reliable enough for rice soil as they are invalidated by comparison with concentration ratios of insitu measurements of greenhouse fluxes. There is no strong relationship between atmospheric pressure and patterns of greenhouse gas production in rice soils. Gas concentrations are remarkably constant despite varying pressure. However, the gas production and atmospheric pressure showed fluctuation during the measurement period. There was not enough organic matter in rice soil for detection organic analysis. However in future the organic matter can be extracted and analysed.
\end{abstract}

Key Words: Methane and carbon dioxide flux, Rice field, Environmental controls, Organic analysis

\section{Introduction}

Very high rate of carbon cycling is occurred through rice cultivation because flooded rice fields are highly productive (55\% of world rice) and huge amount of fertilizer, compost and irrigation are used for the production of rice (IRRI, 1993). Moreover, as a major food source and highly demand for many of the people in the world especially in Asia, rice is cultivated intensively. For instance, in Bangladesh rice is cultivated three times per year in the same land. So, flooded rice fields play important roles in global greenhouse gas budget. Globally, Rice paddies play an important role in greenhouse gas emission such as $\mathrm{CO}_{2}$ and $\mathrm{CH}_{4}$ (IPCC, 1995). There is about $148 \times 10^{6}$ ha wetland rice field in the world which is responsible for $12 \%$ of the total $\mathrm{CH}_{4}$ emission to the atmosphere. The $\mathrm{CH}_{4}$ emission from rice paddies influenced by several factors like growth of the plants, amount of carbon content in soil and management practices such as irrigation, fertilizer, return of organic residues to the soils and the seasonal climate (Neu et al., 1996). The factors controlling the net fluxes between rice field and atmosphere are different from other dry land ecosystem because the rice remains flooded during its growing period (Miyata, 2000).

However, the mechanism and magnitude behind the $\mathrm{CO}_{2}$ flux exchange between the rice paddies and atmosphere is still now unclear. For instance, Tsukamoto (1993) found considerably lower amount of $\mathrm{CO}_{2}$ in drained rice field than flooded rice field but the reason is not fully known. Soil carbon budgets in rice field does not quantified accurately to date due to limited research on flux measurement of rice field specially flooded rice fields (Kimura et al., 2004). Furthermore the data found to date are not enough to observe the effect of atmospheric factors on flux movement between rice paddies and atmosphere (Miyata, 2000). So, rice fields are important source of greenhouse gases but have not been well quantified. Now it is essential to quantify the amount of $\mathrm{CH}_{4}$ and $\mathrm{CO}_{2}$ emitted from rice field. The rate of greenhouse gas sequestration and emission is determined by the variables like temperature, pressure or inundation because these variables show difference in different places and depths. So, it is very important to study the effect of these variables on the emission of greenhouse gases in rice field for prediction how greenhouse gas fluxes may change in the future. Analysis of the organic carbon in the soils can also be useful for determining controls on gas production. Humic acid and polysaccharides are two important components found in the organic soil. It is also possible to determine whether methanotrophs are present in soil through organic analysis. Different methanotrophs are responsible for producing methane by breaking down the components of organic carbon in soil. A number of bacteriohopanepolyols (BHPs) structures have been identified as explicit to particular bacterial species, and used as proxies for the presence of these bacteria in soil (Talbot and Farrimond, 2007). 
For instance, aminobacteriohopanetetrol (1d) and aminobacterioopanepentol (1e), indicators of aerobic methane oxidation, have been observed in all sediments either in water column or terrestrial environment (Coolen et al., 2008).

Gas fluxes are fluctuated because the factors controlling the fluxes are changeable. So, to understand about temporal and spatial variability of gas flux, long-term continuous data is needed (Morris et al, 2008). So, to improve understanding of the factors influencing the fluxes in rice fields, experiments were monitored for longer periods of time with the following objectives: i) To quantify greenhouse gas fluxes from rice soils through both insitu and ex-situ measurement and ii) To improve understanding of the process controlling gas production in soil in order to predict how greenhouse gas fluxes and composition may change in the future. This will help to determine whether there is a relationship between a) Gas concentration with pressure and b) Gas concentration with types of organic carbon also with biomarker evidence of particular microbial communities.

\section{Methodology}

The research area is situated at the rice field of Agriculture Farm of Bangladesh Agricultural University $\left(24.75^{\circ} \mathrm{N}, 90.5^{\circ} \mathrm{E}\right.$, and 18 meters above sea level) which is located to the $6 \mathrm{~km}$ south of Mymensingh town. The GasClam was installed at Boro rice field. The Boro rice was planted on 13 January, 2010 and it was harvested on 13 May, 2010. Soil samples were taken from Boro rice field at four different times from both $0-40 \mathrm{~cm}$ and $40-100 \mathrm{~cm}$ soil depths for ex-situ measurement. Water content was determined by drying to constant weight at $50{ }^{0} \mathrm{C}$ from rice soils. Eight samples were taken from rice soil to measure the water content of the samples. Two samples were taken from the early vegetative stage and other two were taken from late vegetative stage of rice to show the change of organic compounds especially humic acid (phenol) and polysaccharides (primary and secondary polysaccharides) between these two stages. Pyrolysis was performed at $700{ }^{0} \mathrm{C}$ by CDS 5200 pyroprobe unit (Analytical Inc., Pyroprobe 5000 series), fitted with an platinum coil interfaced to an 7890A gas chromatograph (Agilent Technologies) coupled to a 5975C MSD (Agilent Technologies) mass spectrometer operated in electron ionization (EI) mode (scanning a range from $\mathrm{m} / \mathrm{z} 50$ 600 at 2.7 scan s $^{-1}$, ionisation energy $40 \mathrm{eV}$ ). For exsitu measurement of the soil, the collected soil samples were kept into a special glass bottle and 5 $\mathrm{NaOH}$ pellet were put in each bottle, then cap was tighten. For anaerobic measurement, the bottle was purged with nitrogen and kept in incubated condition while for aerobic measurement the bottle was kept in incubated condition without purged with nitrogen. After 7 days the changes of pressure was measured from the bottle of soil sample through oxytops. In anaerobic bottle, an increase in pressure is assumed to be a result of $\mathrm{CH}_{4}$ production. In aerobic bottles, a decrease in pressure is assumed to be a result of the use of oxygen which is equivalent to $\mathrm{CO}_{2}$ production. Finally the pressure was converted to mole/ tonne dry weight soil/day. The in-situ measurement was done by using Gasclam. The Gasclams were inserted into boreholes at shallow $(0-40 \mathrm{~cm})$ and deep soil (40-100 $\mathrm{cm})$. The data from the Gasclam was retrieved after several weeks. The duration of the measurement was from 1 March to 21 April, 2010.

\section{Results and Discussions}

\section{Characterization of Rice Soil}

Water content rice soil: The average water content of rice soil at shallow depth was $25.39 \%$ while the deep soil contained $28.16 \%$ water.

Organic compound present in rice soil

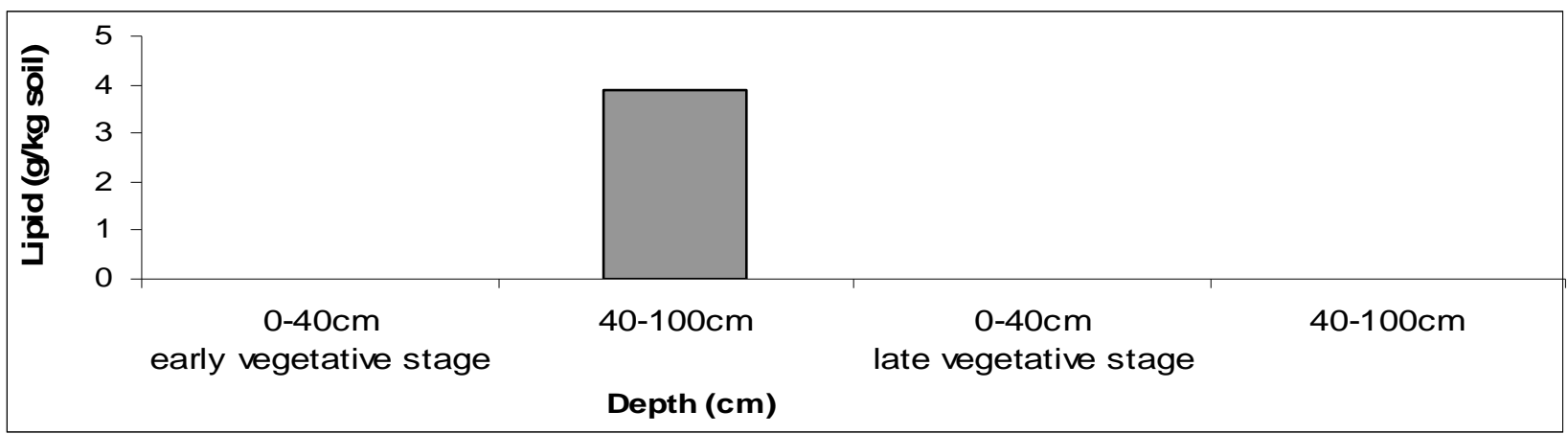

Figure 1: Organic compound present in soil 


\section{Quantification of gas production from rice soil}

Table 1. Rates and Ratios of ex-situ and in-situ gas production of rice field

\begin{tabular}{|c|c|c|c|c|c|c|}
\hline & \multicolumn{3}{|c|}{ Rate } & \multicolumn{2}{c|}{ Ratio } \\
\hline Site & $\begin{array}{c}\text { Ex-situ (Mole/tonne dry } \\
\text { weight/day) }\end{array}$ & \multicolumn{2}{c|}{ In-situ (\%) } & Ex-situ & In-situ \\
\hline & $\mathbf{C H}_{\mathbf{4}}$ & $\mathbf{C O}_{\mathbf{2}}$ & $\mathbf{C H}_{\mathbf{4}}$ & $\mathbf{C O}_{\mathbf{2}}$ & $\left.\mathbf{( C H}_{\mathbf{4}}: \mathbf{C O}_{2}\right)$ & $\left(\mathbf{C H}_{\mathbf{4}}: \mathbf{C O}_{\mathbf{2}}\right)$ \\
\hline $\begin{array}{c}\text { Shallow } \\
(0-40 \mathrm{~cm})\end{array}$ & 0.07 & 0.23 & 0.34 & 6.37 & $0.2: 1$ & $0.05: 1$ \\
\hline $\begin{array}{c}\text { Deep } \\
(40-100 \mathrm{~cm})\end{array}$ & 0.09 & 0.29 & -0.03 & 24.70 & $0.7: 1$ & $0.001: 1$ \\
\hline
\end{tabular}

Table 1 showed the rates and ratios of ex-situ and insitu measurement of $\mathrm{CO}_{2}$ and $\mathrm{CH}_{4}$ at both shallow and deep rice paddy soil. In ex-situ measurement deep soil showed the higher rates of production of $\mathrm{CO}_{2}$ and $\mathrm{CH}_{4}$ than shallow soil. In in-situ measurement the average $\mathrm{CH}_{4}$ production rate was higher at shallow soil $(0.34 \%)$ and $\mathrm{CO}_{2}$ production rate was higher at deep soil $(24.70 \%)$. There was not similarity between ex-situ and in-situ ratios of gas production.

\section{In-situ gas production from shallow $(0-40 \mathrm{~cm})$ and deep (40-100) soil}

The concentrations of $\mathrm{CO}_{2}, \mathrm{CH}_{4}$ at shallow rice soil were shown in the Figure $2 \mathrm{a}-\mathrm{b}$. In shallow rice soil, the concentration of $\mathrm{CH}_{4}$ varied from $0.1 \%$ to $0.7 \%$ through out the measurement period and the concentrations were lower during early vegetative stage of rice while the concentration was higher during ripening stage of rice. The amount of $\mathrm{CO}_{2}$ production was more than 5 per cent (Figure 2b). After March 21, the value of $\mathrm{CO}_{2}$ was constant because $5 \% \mathrm{CO}_{2}$ sensor was used at shallow rice soil. The gas concentration showed variation on a range of timescale. On the otherhand, in deep soil, $\mathrm{CH}_{4}$ concentration was only $0.2 \%$ while the $\mathrm{CO}_{2}$ concentration was fluctuated from $2.3 \%$ to $33 \%$ (Figure 3c-d). The production of $\mathrm{CH}_{4}$ was higher at shallow depth soil than deep soil while the concentration of $\mathrm{CO}_{2}$ at deep rice soil was higher than shallow rice soil.
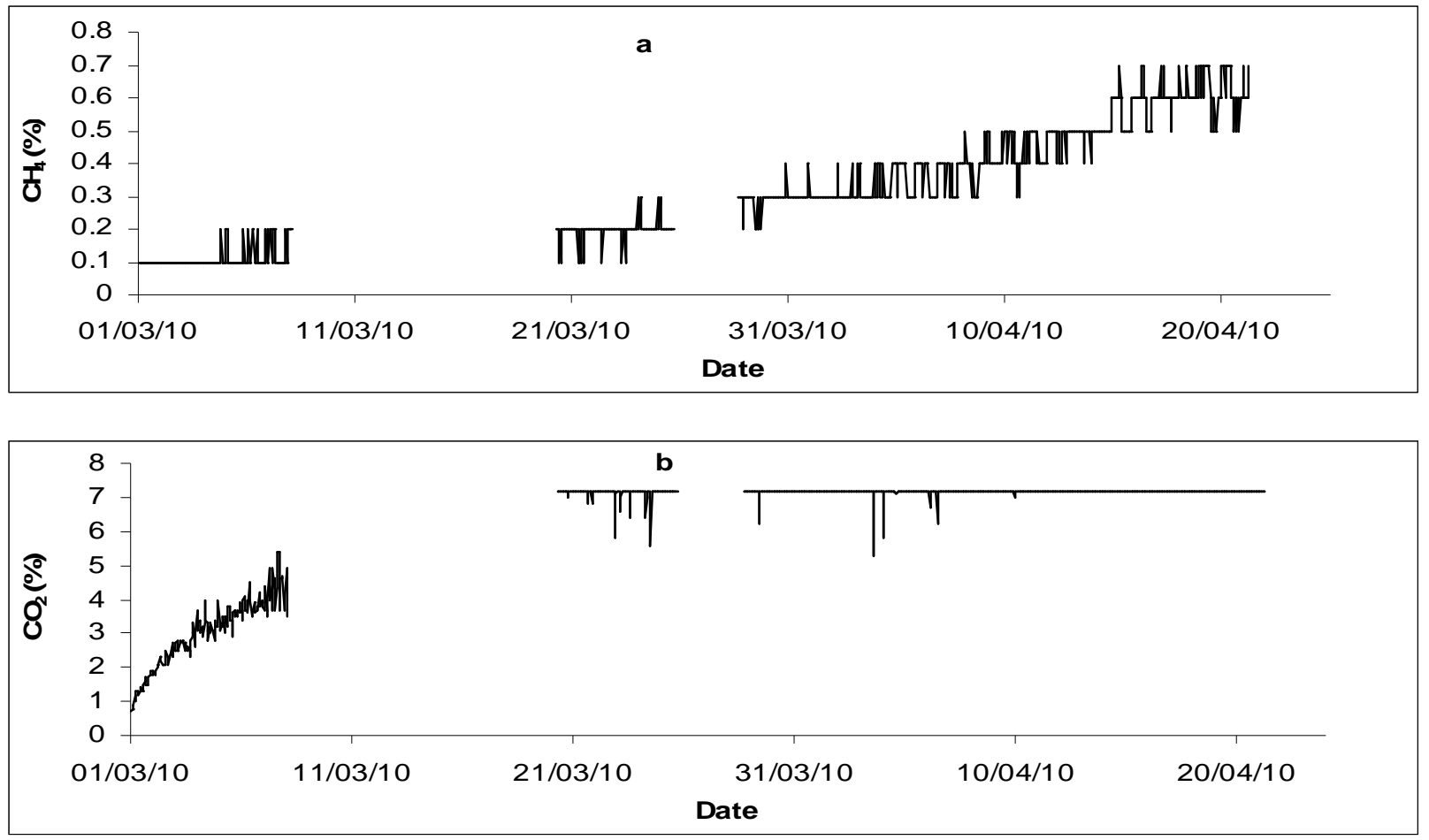

Figure 2: In-situ gas production from shallow rice soil (a-b)

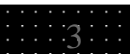



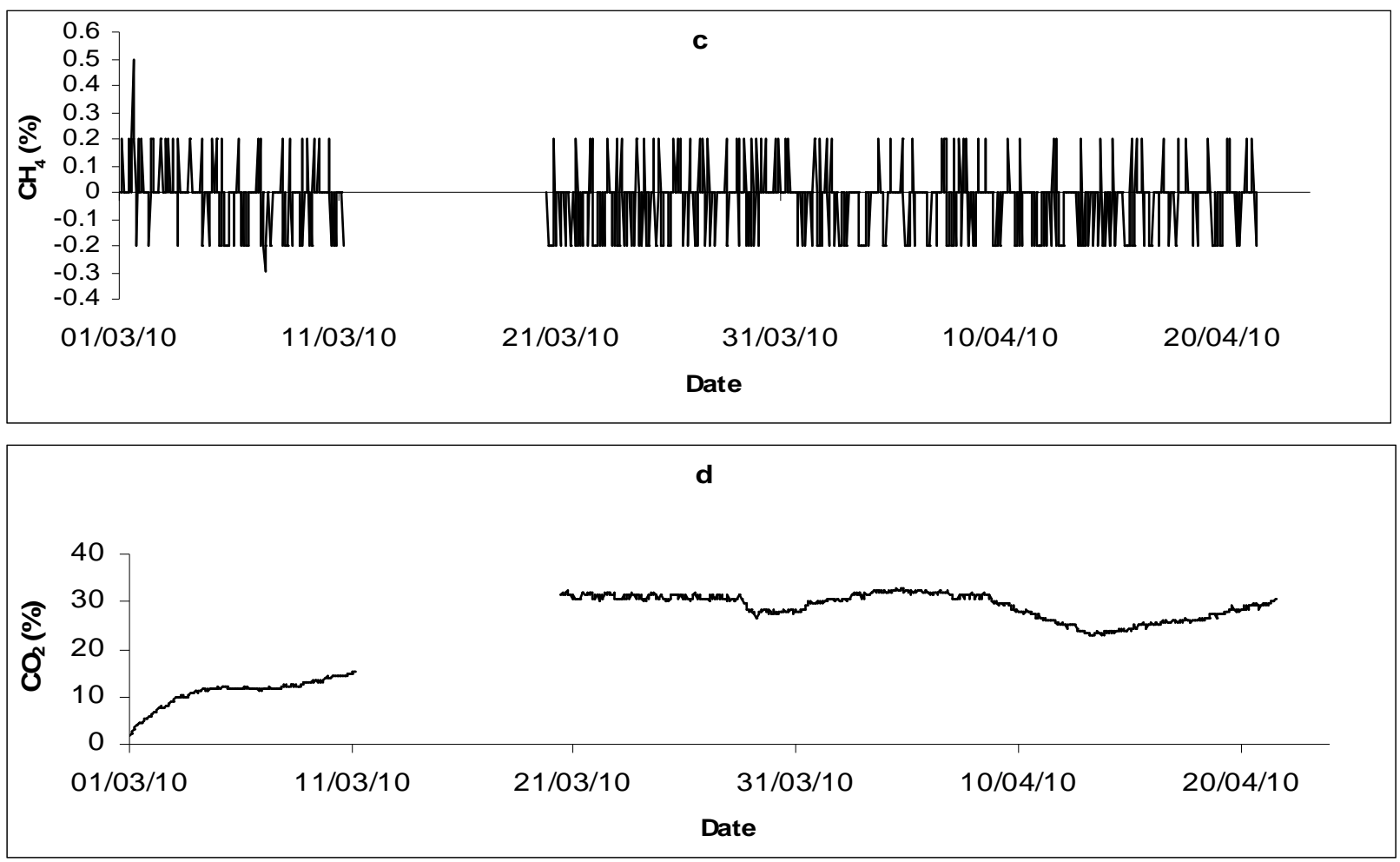

Figure 3: In-situ gas production from deep rice soil (c-d)

Relationship between gas production and atmospheric pressure
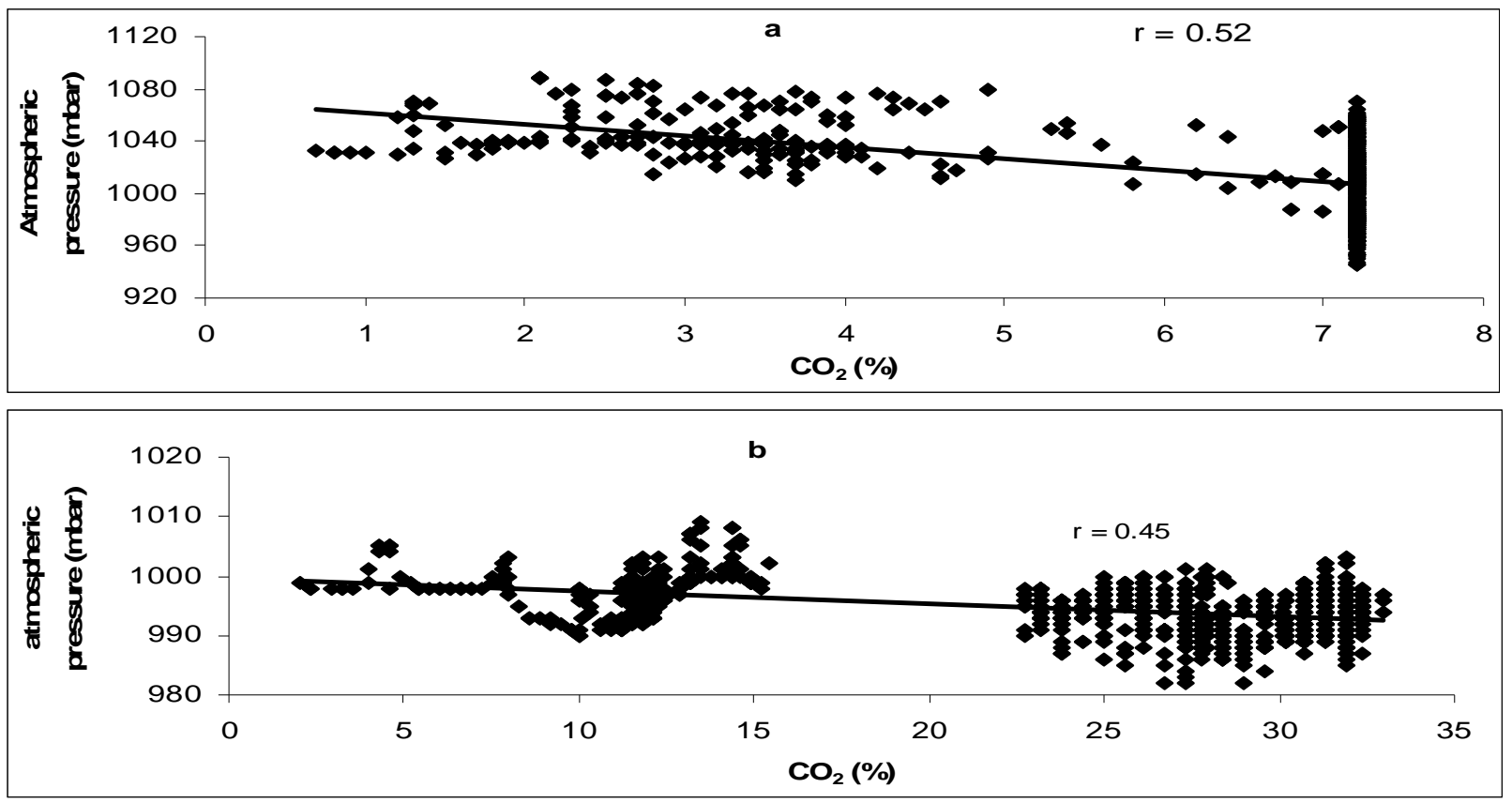

Figure 4: Relationship between gas concentration and atmospheric pressure of shallow and deep rice soil

Figure $4 \mathrm{a}-\mathrm{b}$ showed the relationship between atmospheric pressure and $\mathrm{CO}_{2}$. The $\mathrm{CO}_{2}$ concentration showed inverse relationship with atmospheric pressure; the gas production decreased with the increased of atmospheric pressure. 


\section{Discussion}

In ex-situ measurement the production rate of $\mathrm{CH}_{4}$ at shallow and deep rice soil was 0.07 mole/tonne dry weight soil/day and 0.09 mole/tonne dry weight soil/day, respectively. On the otherhand the production rate of $\mathrm{CO}_{2}$ in shallow and deep rice soil was $0.23 \mathrm{~mole} /$ tonne dry weight soil/day and 0.29 mole/tonne dry weight/day, respectively. Maximum daily uptake of $\mathrm{CO}_{2}$ was $9.2-9.5 \mathrm{~g} \mathrm{C} \mathrm{m}^{-2} \mathrm{~d}^{-1}$ in the middle growing period (Miyata et al., 2005). The average methane emission from rice field in California was $0.25 \mathrm{~g} \mathrm{~m}^{-2}$ while the highest value was $5 \mathrm{~g} \mathrm{~m}^{-2} \mathrm{~d}^{-1}$ and it was found just 2-3 weeks before harvesting (Cicerone and Shetter, 1983). In in-situ measurement, the average production rate of $\mathrm{CH}_{4}$ in shallow rice soil was $0.34 \%$ while at deep soil it was very low. The $\mathrm{CO}_{2}$ concentration at shallow and deep soil was $6.37 \%$ and $24.70 \%$, respectively. At shallow rice soil the ratios of $\mathrm{CH}_{4}$ and $\mathrm{CO}_{2}$ of ex-situ and insitu measurement soil was $0.2: 1$ and $0.05: 1$ while in deep rice soil the ratio of $\mathrm{CH}_{4}$ and $\mathrm{CO}_{2}$ was $0.7: 1$ and $0.001: 1$, respectively. In rice soil, ex-situ measurement showed higher ratios than in-situ at both shallow and deep soil. So, there is no similarity in rates and ratios of gas production between in-situ and ex-situ measurement. The higher concentration of $\mathrm{CH}_{4}$ was produced at shallow rice soil while higher amount of $\mathrm{CO}_{2}$ was produced at deep soil. However, the $\mathrm{CH}_{4}$ emission from rice paddies influenced by several factors like growth of the plants, amount of carbon content in soil and management practices such as irrigation, fertilizer, return of organic residues to the soils and the seasonal climate. Moreover, the emission rate of methane in the rice field depends on both production rate in the submerge soil and developmental phase of plants.However, there is no strong relationship between atmospheric pressure and the production of gases found in this measurement. Gas concentration has been suspected to vary with changing atmospheric pressure but not much changed has been noticed here - gas concentrations are remarkably constant despite varying pressure. Humic acid and polysaccharides (primary and secondary polysaccharide) were not found from the soil sample through pyrolysis. So, there was not enough organic matter for organic analysis. However, in the future the organic matter could be extracted and analysed. Absent (below lower detection limit) of humic acid and polysaccharides in rice soils give information about the lower amount of organic matter present in rice soil, Bangladesh.

\section{Conclusion}

Main limitation of the investigation was insufficient representativeness of the data. Longer set of timeseries data is needed in order to increase the reliability of the data and to address the objectives of the research because longer set of time-series would be helpful for understanding how gas production and migration in soil are influences because of climate change. However, there are some plausible inferences that we can draw from the data we have obtained:

I. In ex-situ measurement the production rate of $\mathrm{CH}_{4}$ at shallow and deep rice soil was 0.07 mole/tonne dry weight soil/day and 0.09 mole/tonne dry weight soil/day, respectively. On the otherhand the production rate of $\mathrm{CO}_{2}$ in shallow and deep borehole was 0.23 mole/tonne dry weight soil/day and 0.29 mole/tonne dry weight soil/day, respectively. In in-situ measurement the average production rate of $\mathrm{CH}_{4}$ in shallow soil was $0.34 \%$ while at deep soil it was very low. The $\mathrm{CO}_{2}$ concentration at shallow and deep soil was $6.37 \%$ and $24.70 \%$, respectively.

II. The ex-situ measurements of greenhouse gas fluxes are not reliable enough for rice soil as they are invalidated by comparison with concentration ratios of in-situ measurements of greenhouse fluxes.

III. There is not strong relationship between atmospheric pressure and patterns of greenhouse gas production in rice soils. Gas concentrations are remarkably constant despite varying pressure. However, the gas production and atmospheric pressure showed fluctuation during the measurement period

IV. There was not enough organic matter for detection organic analysis. However in future the organic matter can be extracted and analysed.

\section{References}

Cicerone, R.J. and Shetter, J.D. 1983. Seasonal variation of methane flux from a California rice paddy. Journal of Geophysical Research, 88: 11022-11024.

Coolen, M. J. L.; Talbot, H. M.; Abbas, B. A.; Ward, A.; Schouten, S.; Volkman, J. K. and Sinninghe Damste, J. S. 2008. Sources for sedimentary bacteriohopanepolyols as revealed by $16 \mathrm{~S}$ rDNA stratigraphy. , . Environmental Microbiology, 10:1783-1803.

International Panel on Climate Change (IPCC). 1995. Climate Change 1995: The Science of Climate Change. In: Houghton, J.T.; Meira Filho, L.G.; Callander, B.A.; Harris, N.; Kattenberg, A. and Maskell, K. (Eds.), Cambridge Univ. Press, Cambridge. 
International Rice Research Institute (IRRI). 1993. IRRI Rice Almanac, IRRI, Los BanÄos, Philippines.

Kimura, M.; Murase, J. and Lu, Y. 2004. Carbon cycling in rice field ecosystems in the context of input, decomposition and translocation of organic materials and the fates of their end products $\left(\mathrm{CO}^{2}\right.$ and $\left.\mathrm{CH}^{4}\right)$. Soil Biol. Biochem, 36: 1399-1416.

Miyata, A.; Leuning, R.; Denmead, O. T.; Kim, J. and Harazono, Y. 2000. Carbon dioxide and methane fluxes from an intermittently flooded paddy field. Agricultural and Forest Meteorology, 102: 287-303.

Miyata, A.; Iwata, T.; Nagai, H.; Yamada, T.; Yoshikoshi, I.T.; Mano, M.; Ono, K.; Han, G.H.; Harazono, Y.; Ohataki, E.; Baten, M.A.; Inohra. S.; Takimot, T. and Saito, M.
2005. Seasonal variation of carbon dioxide and methane fluxes at single cropping paddy fields in central and western Japan. Phyton (Austria) Special issue: 'APGC 2004', 45: 89-97.

Neu, H.-U.; Lantin, R. L.; Alberto, M. C. R.; Aduna, J. B. and Javellana, M. A. 1996. Factors affecting methane emission from rice fields. Atmos. Environ., 30: 1751- 1754

Talbot, H. M. and Farrimond, P. 2007. Bacterial populations recorded in diverse sedimentary biohopanoid distributions. Organic Geochemistry, 38: 1212-1225.

Tsukamoto, O. 1993. Turbulent fluxes over paddy field under various ponding depth. J. Agric. Meteorol., 49: 19-25 (in Japanese with English abstract and captions). 